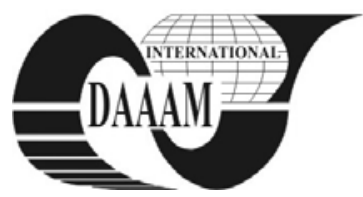

\title{
PROGRAMMING TIME ESTIMATION AND PRODUCTION PLANNING STEPS ON WELDING ROBOT CELLS IN SME-S
}

\author{
SARKANS, M[artins] \& EERME, M[artin]
}

\begin{abstract}
Robot welding in small and medium-sized enterprises (SMEs) poses new challenges concerning the programming of robots and production planning. In this context, a methodology is presented to estimate the robot programming time suitable for small product batches. On this basis a new approach to the estimation of the product suitability for robot welding is proposed with the aim to increase the competitiveness of SMEs. Finally, guidelines for production planning are given, taking into account different production quantities and products with different complexity.
\end{abstract}

Key words: robot welding cell, robot programming, programming time, production planning

\section{INTRODUCTION}

The implementation of industrial robots in SMEs was an increasing trend in previous decade (Nilsson, 2005) and still is. It has been called forth by the development of robot programming possibilities and cheaper prices of robots, which make them suitable for SMEs. In connection with this, a number of topics arise concerning robot welding in case of small batches such as programming, production planning, jig development and system implementation.

Some issues such as robot calibration, programming (Ong, 2010), production scheduling (Zachaaria, 2005), selection of robots (Kouloriotis, 2011) and welding support (Erden, 2011) can be easily transformed under the conditions of small batches but they need substantial revision.

In the present article a methodology is proposed for estimating the programming time for making a welding program under the conditions of online robot programming. This approach includes additional movements, cleaning procedures and guidelines for production planning for different production quantities and products. Decisions about the suitability of a product for robot welding cell production can be made by dividing the products into groups by production time and batch size.

\section{PROGRAMMING TIME ESTIMATION}

One of the major parameters when using robot welding is the estimation of programming time. When production batches are small and change rapidly, the capability to estimate the programming time gives SMEs advantages. In this approach the evaluation of single-pass welds and gas metal arc welding (GMAW) is proposed. The robot is programmed online using a teach-pendant.

The case studies of four different welding robot cells provide a basis for the development of the methodology for estimating the programming time. These cells were implemented in SMEs, the product nomenclature on each cell exceeding 10 products on each robot. The data was gathered between the years 2007 and 2010 .

During the research it appeared that not all the parameters are of the same importance when estimating the programming time. The overall length of welds in the product, the number of welds of the product, the number of measurements in the program and the volume of the product proved to be the most influential parameters. However, it is also important to include factors such as the number of movements between the welds and the number of tool cleaning movements. The accuracy of the final result can be significantly increased by dividing the programming process into smaller sub-processes/operations.

The approximate duration of each programming suboperation must be defined before the calculation of programming time $t_{p r}$. The exact values are difficult to define, because they vary from product to product and program to program. The recommended programming times can be used as shown after Equation 1.

The estimation of programming time $\left(t_{p r}\right)$ is shown in Equation 1:

$$
\begin{gathered}
t_{p r}=\left(t_{w} * n_{w}+t_{m e} * n_{m e}+t_{m v} * n_{m v}+\right. \\
\left.+t_{c l} * n_{c l}\right) * C_{c o}
\end{gathered}
$$

where:

$\mathrm{t}_{\mathrm{w}}$ - time for programming one welding movement, (180 $\mathrm{s}$ to $240 \mathrm{~s})$;

$\mathrm{n}_{\mathrm{w}}$ - number of welds in the program;

$\mathrm{t}_{\mathrm{me}}$ - time for programming one measuring movement, (120 s to $180 \mathrm{~s})$;

$\mathrm{n}_{\mathrm{me}}$ - number of measurements in the program;

$\mathrm{t}_{\mathrm{mv}}$ - time for programming one additional movement, (60 $\mathrm{s}$ to $120 \mathrm{~s})$

$\mathrm{n}_{\mathrm{mv}}$ - number of additional movements in the program;

$\mathrm{t}_{\mathrm{cl}}$ - time for programming tool cleaning movements, $(120 \mathrm{~s}$ to $180 \mathrm{~s})$;

$\mathrm{n}_{\mathrm{cl}}$ - number of tool cleaning movements in the program;

$\mathrm{C}_{\mathrm{co}}$ - coefficient of product complexity on programming time.

As the products differ from each other concerning their configuration and production technology, the coefficient of product complexity on programming time is included in this equation. The coefficient is based on the gathered and analyzed data from the case studies mentioned previously.

To determine the complexities and weight of different parameters $\left(n_{m e}, l_{w}, d_{v}, n_{w}\right)$ Table 1 was compiled. It is mainly a recommendation and can be integrated with enterprise specific data.

\begin{tabular}{|l|l|l|l|l|l|l|}
\hline \multicolumn{9}{|l|}{ Complexity } & & \\
\hline $\begin{array}{l}\text { sym- } \\
\text { bol }\end{array}$ & unit & Easy & ordinary & complex & $\begin{array}{l}\text { very } \\
\text { complex }\end{array}$ & Weight \\
\hline $\mathrm{n}_{\mathrm{me}}$ & pcs & $1 \ldots 5$ & $6 \ldots 15$ & $16 \ldots 30$ & $31 \ldots 50$ & $35 \%$ \\
\hline $\mathrm{l}_{\mathrm{w}}$ & $\mathrm{m}$ & $0,1 \ldots 1$ & $1,1 \ldots 5$ & $5,1 \ldots 10$ & $10,1 \ldots 30$ & $25 \%$ \\
\hline $\mathrm{d}_{\mathrm{v}}$ & $\mathrm{m}^{3}$ & $0,1 \ldots 0,4$ & $0,5 \ldots 0,9$ & $1 \ldots 1,49$ & $1,5 \ldots 2$ & $10 \%$ \\
\hline $\mathrm{n}_{\mathrm{w}}$ & pcs & $1 \ldots 5$ & $6 \ldots 20$ & $21 \ldots 50$ & $51 \ldots 100$ & $30 \%$ \\
\hline $\mathrm{C}_{\mathrm{co}}$ & 1 & 2 & 3 & 4 & \\
\hline
\end{tabular}

Tab. 1. Selection of parameters for calculating the coefficient of product complexity on programming time 
As shown in Table 1 the following groups are formed: easy, ordinary, complex and very complex. These intervals are defined based on the analysis of different products. The weights of the parameters for increasing complexity are also given. For example, the increase in the product volume does not influence the complexity as much as the increase in measurements in the program.

The calculation of the coefficient of product complexity on programming time $\left(\mathrm{C}_{\mathrm{co}}\right)$ is given in Equation 2:

$$
\begin{gathered}
C_{c o}=0,35 * n_{m e}^{c o}+0,25 * l_{w}^{c o}+0,10 * d_{v}^{c o}+ \\
+0,30 * n_{w}^{c o}
\end{gathered}
$$

where:

$\mathrm{C}_{\mathrm{co}}$ - coefficient of complexity;

$n_{m e}^{c o}$ - coefficient of the number of measuring;

$l_{w}^{c o}$ - coefficient of the welding length;

$d_{v}^{c o}$ - coefficient of the product volume;

$n_{w}^{c o}$ - coefficient of the number of welds.

\section{PRODUCT SUITABILITY ESTIMATION}

To estimate product suitability for production in a robot welding cell in case of small batches the parameters such as programming time, welding time, production quantity and program running time are important to define.

The following findings were made. When the welding length and programming time of the product increase, production quantity can decrease while the batch size must fill a work shift per month during the product life-cycle for at least a year (the base-frame of mini-loaders). When the welding length and programming time of the product decrease, the production quantity must increase and the batch size must fill a work shift per week (a hydraulic cylinder). It can be shown that the product with smaller dimensions and fewer welds holds lower complexity than the product with bigger dimensions and the requirement for additional measurements. The complexity rises as the number of welds increases and the technological sequence must receive more attention. As the dimensions of the product increase, the programming space expands and the complexity rises.

As an example, two different products, the base frame (Fig. 1a) and the fuel tank (Fig. 1b) of a mini-loader, are compared to show the influence of the complexity coefficient. The data about the products (welding length, number of measurements, number of welds and volume) and the values of the complexity coefficient are given in Table 2.

The estimated programming time for the base frame of mini-loaders is between 32.2 and $58.4 \mathrm{~h}$ and for the fuel-tank between 5.1 and $9.3 \mathrm{~h}$ respectively.

The values are given as minimum and maximum as they depend on the duration of the used programming operations. As the programming knowledge increases, the values can be refined by the enterprise specific data.

In order to collect such data, additional sensors can be used in robot-welding cells. As there are many moving parts in the system, wireless sensors are the most suitable (Otto, 2011). Also, they enable to monitor the maintenance of the system.

\begin{tabular}{|l|l|l|l|l|l|l|}
\hline & $\begin{array}{l}\mathrm{l}_{\mathrm{w}} \\
(\mathrm{m})\end{array}$ & $\begin{array}{l}\mathrm{n}_{\mathrm{me}} \\
(\mathrm{pcs})\end{array}$ & $\begin{array}{l}\mathrm{n}_{\mathrm{w}} \\
(\mathrm{pcs})\end{array}$ & $\begin{array}{l}\mathrm{n}_{\mathrm{cl}} \\
(\mathrm{pcs})\end{array}$ & $\begin{array}{l}\mathrm{d}_{\mathrm{v}} \\
\left(\mathrm{m}^{3}\right)\end{array}$ & Sum \\
\hline $\begin{array}{l}\text { Base- } \\
\text { frame }\end{array}$ & 15,1 & 8 & 92 & 8 & 0,53 & \\
\hline $\mathrm{C}_{\mathrm{co}}$ & 4 & 2 & 4 & $\mathrm{NA}$ & 2 & 3,1 \\
\hline $\begin{array}{l}\text { Fuel- } \\
\text { tank }\end{array}$ & 5,55 & 0 & 25 & 4 & 0,075 & \\
\hline $\mathrm{C}_{\mathrm{co}}$ & 3 & 0 & 3 & $\mathrm{NA}$ & 1 & 1,75 \\
\hline
\end{tabular}

Tab. 2. Product data of the base-frame and fuel-tank and the overall values of the complexity coefficient.

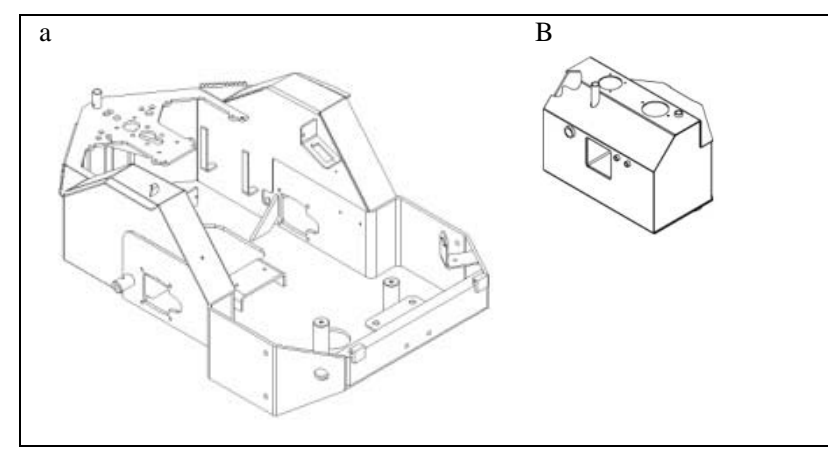

Fig. 1. Mini-loaders base-frame (a) and fuel-tank (b)

\section{CONCLUSION}

A fresh look has been taken at the evaluation of the suitability of robot welding under the conditions of SMEs. This approach was tested on the experience of exploiting 4 different robot welding cells. The proposed methodologies for estimating the programming time and product suitability for robot welding under the conditions of small batches turned out to be suitable for all the explored robot welding cells. Hence, the guidelines for production planning can be recommended in order to increase the competitiveness of SMEs.

The future research will focus on the analysis of the data and knowledge gathered in 2007-2010 to help the SMEs with the implementation of robot welding cells. This approach enables to evaluate the approximate implementation time of the whole new robot welding cell.

\section{ACKNOWLEDGEMENTS}

The research was supported by the Innovative Manufacturing Engineering Systems Competence Centre (IMECC), co-financed by Enterprise Estonia (EAS) and the European Union Regional Development Fund (project EU30006), the Estonian Science Foundation (ESF) (Grant No 7852) and the graduate school „Functional materials and processes“ receiving funding from the European Social Fund under project 1.2.0401.09-0079 in Estonia.

\section{REFERENCES}

Erden, M. S. \& Marić, B. (2011). Assisting manual welding with robot. Robotics and Computer-Integrated Manufacturing, Vol. 27, 4, 2011, 818-828, ISSN 0736-5845

Koulouriotis, D. E. \& Ketipi, M. K. (2011). A fuzzy diagraph method for robot evaluation and selection. Expert Systems with Applications, Vol. 38, 9, 2011, 11901-11910, ISSN 0957-4174

Nilsson, K.; Johansson, R.; Robertsson, A.; Bischoff, R.; Brogårdh, T. \& Hägele, M. (2005). Productive robots and the SMErobot project, Third Swedish Workshop on Autonomous Robotics, Available from: http://www.smerobot.org Accessed: 2011-09-20

Ong, S. K.; Chong, J. W. S. \& Nee, A. Y. C. (2010). A novel AR-based robot programming and path planning methodology. Robotics and Computer-Integrated Manufacturing, Vol. 26, 3, 2010, 240-249, ISSN 0736-5845

Otto, T.; Aruväli, T.; Serg, R. \& Preden, J. (2011). In process determining of the working mode in CNC turning. Estonian Journal of Engineering. Vol. 17, 1, 2011, 4-16, ISSN 14060175

Zachaaria, P. T. \& Aspragathos, N. A. (2005). Optimal robot task scheduling based on genetic algorithms. Robotics Computer-Integrated Manufacturing, Vol. 21, 1, 2005, 6779, ISSN 0736-5845 